\title{
LANKESTERIANA, A NEW GENUS IN THE PLEUROTHALLIDINAE (ORCHIDACEAE)
}

\author{
AdAm P. KaRREMANS \\ Lankester Botanical Garden, University of Costa Rica, P.O. Box 302-7050 Cartago, Costa Rica. \\ Naturalis Biodiversity Center - NHN Universiteit Leiden, The Netherlands \\ adam.karremans@ucr.ac.cr
}

\begin{abstract}
AвSTRACT. We estimated phylogenetic relationships within Anathallis and related genera using Bayesian analyses of nrITS sequence data. The genus is biphyletic in the molecular trees. A novel generic concept, Lankesteriana, is proposed for the species Anathallis barbulata and 19 close relatives. The genus is more closely related to some species of Trichosalpinx and Zootrophion than to Anathallis s.s. Species previously transferred from Pleurothallis subgen. Acuminatia sect. Acuminatae to Anathallis, are here transferred to Stelis, to which they are related phylogenetically. A few additional transfers to Anathallis are made. Lankesteriana is described and characterized, and the necessary taxonomic transfers are made.
\end{abstract}

KeY words: Anathallis, Lankesteriana, Specklinia, Stelis, phylogenetics, systematics

Introduction. The most recent reorganization of the generic classification of the Pleurothallidinae proposed by Pridgeon and Chase (2001) was largely based on the results of the molecular phylogenetic studies of the subtribe (Pridgeon et al. 2001). The initial analyses were made on a representative set of species and their results were extrapolated to the whole subtribe by correlation with the classification previously proposed by Luer (1986), based on morphological similarities. The circumscription of each genus was discussed and refined by Pridgeon (2005).

Subsequent molecular studies have shown that several of the genera of Pleurothallidinae still require a modified circumscription in order to comply with the monophyly criterion. Anathallis Barb.Rodr. is no exception. In the phylogenetic trees of Pridgeon et al. (2001), species of Pleurothallis R.Br. subgen. Acuminatia Luer (Luer 1999), including the type species of genus Anathallis, formed a clade together with species of Pleurothallis subgen. Specklinia sect. Muscosae Lindl. The clade was found sister to a clade which includes Trichosalpinx Luer and Lepanthes Sw., among others, and a broad concept of genus Anathallis was re-established (Prodgeon \& Chase 2001; Pridgeon 2005).
However, Pridgeon's data set included only species of Pleurothallis subgen. Acuminatia sect. Alatae Luer and did not include representatives of sect. Acuminatae Lindl. had been initially analyzed. Karremans (2010) noted that species belonging to sect. Acuminatae were not related to those of sect. Alatae, but instead were found embedded within Stelis Sw. (sensu Pridgeon 2005), and suggested that, based on morphology, the same would be true for all other species in the section. The studies by Chiron et al. (2012) and Karremans et al. (2013a) confirmed that additional species of the sect. Acuminatae belonged in Stelis. The first set of authors even proposed a new combination for Anathallis rubens (Lindl.) Pridgeon \& M.W.Chase in Stelis, but neglected to transfer all other species of the section.

Luer (2006) later segregated species of Pleurothallis subgen. Specklinia (Lindl.) Garay sect. Muscosae Lindl. into Panmorphia Luer resulting in a genus of 73 highly heterogeneous species with "Specklinia-like habit and Anathallis-like flowers". Luer later decided that the variation within Panmophia graded into the concept of Anathallis, and he reduced his Panmophia as a synonym of the latter (Luer 2009). Analyses of molecular data by Stenzel (2004) demonstrated that species of Panmorphia (including the type) were embedded within Anathallis.

* This paper was prepared in the framework of the celebration of Lankester Botanical Garden's $40^{\text {th }}$ anniversary. 
This conclusion was confirmed by Chiron et al. (2012), who included a broad representation of Anathallis species in their analyses.

One Anathallis species, the broadly distributed and highly variable Anathallis barbulata (Lindl.) Pridgeon \& Chase, was shown to be distinct from all the other species (Chiron et al. 2012). It is probably the most well known species of the group here discussed. In Luer's subgeneric classification of genus Pleurothallis R.Br., A. barbulata and a few close relatives were placed in Pleurothallis subgen. Specklinia sect. Muscosae Lindl. (Luer 1986). Later on, they were transferred to Anathallis by Pridgeon and Chase (2001) and Panmorphia by Luer (2006). We present nrITS analyses showing that most species of Panmorphia, including the type species, Anathallis sertularioides (Sw.) Pridgeon \& Chase, are embedded within Anathallis. Our data also show that Anathallis barbulata and a few sister species are not closely related to other Anathallis and require generic recognition to maintain monophyly.

Most of these Specklinia-like species of Anathallis have also been treated as species of Specklinia Lindl. at some point or another. A more extensive molecular phylogenetic analysis of Specklinia (Karremans et al. unpublished), excludes the species here treated as Anathallis (Pupulin et al. 2012, Bogarín et al. 2013, Karremans et al. 2013b), requiring the circumscription of those genera in the present manuscript. It becomes necessary as well to propose the systematic modifications required in order to attain monophyly within Anathallis, Specklinia, and Stelis and to propose a segregated generic concept for the $A$. barbulata and its close relatives.

Material and Methods. This study was conducted at Jardín Botánico Lankester (JBL) of the Universidad de Costa Rica and Naturalis Biodiversity Center - Leiden University, between October 2011 and October 2013. Living material was studied at Lankester Botanical Garden and the Hortus Botanicus in Leiden, while dried and spirit material was deposited at CR, JBL-spirit and L-spirit. Taxon names mostly follow Pridgeon (2005).

Photography - Color illustrations of complete flowers were made using a Nikon D5100 digital camera, while photographs of the columns and pollinaria were taken using a DFC295 Leica digital microscope color camera with Leica FireCam version 3.4.1 software. Scanning electron microscope (SEM) micrographs were taken from flowers fixed in FAA (formalin 10\%, glacial acetic acid $5 \%$, water $35 \%$, ethanol $50 \%$ ). The floral samples were then dehydrated through a series of ethanol steps and subjected to critical-pointdrying using liquid $\mathrm{CO}_{2}$. Dried samples were mounted and sputter-coated with gold and observed with a JEOL JSM-5300 scanning electron microscope at an accelerating voltage of $10 \mathrm{kV}$.

Phylogenetic analysis - . The data matrix included 56 individuals (Table 1), 18 of which were produced in this study. The remaining data were obtained from GenBank (Pridgeon et al. 2001, Chiron et al. 2012, Karremans et al. 2013a). Plants were obtained from living collections at Lankester Botanical Garden in Costa Rica, the Hortus Botanicus in Leiden, and private collections. Vouchers were deposited in spirit collections at JBL and L. Fresh leaf and flower cuttings of approximately $1 \mathrm{~cm}^{2}$ were dried with silica gel. Samples $(20 \mathrm{mg})$ were pulverized and extraction performed following the DNEasy procedure (Qiagen). The nuclear ribosomal internal transcribed spacer (nrITS) region was amplified using the methods and primers for sequencing and amplification described by Sun et al. (1994), and Sanger sequencing was done commercially by Macrogen on a 96-capillary 3730x1 DNA Analyzer automated sequencer (Applied Biosystems, Inc.) using standard dye-terminator chemistry (Macrogen, Inc.).

The Staden et al. (2003) package was used for editing of the sequences. Contigs were exported as .fas files and opened in Mesquite v2.72 (Maddison \& Maddison 2007), where they were checked for base calling errors, the matrix was aligned manually. The ends of each data set were trimmed to eliminate possible erroneous data, and gaps were regarded as missing data (filled with Ns). The data matrix is deposited in the Dryad Digital Repository (Heneghan et al. 2011). Echinosepala aspasicensis was used as the outgroup, as it was found to be one of the most distantly related of all included species (Pridgeon et al. 2001). The trees were produced with an analysis of the nrITS dataset of 43 sequences using BEAST v1.6.0. (Drummond \& Rambaut 2007). Parameters 
were set to preset, except for substitution model GTR with 10 categories, clock model uncorrelated lognormal, tree prior Yule process, and number of generations 20,000,000. The resulting trees were combined using TreeAnnotator v1.6.0., where the first 2000 trees were used as burn-in. FigTree v1.3.1. (Rambaut 2009) was used to edit the resulting tree. Posterior probabilities are given for each node in decimal form.

Results. The consensus gene tree (Fig. 1) was obtained from a BEAST analysis of a matrix of 56 ITS sequences (Table 1), including 41 individuals belonging to 34 different species of genus Anathallis. The resulting tree includes two highly supported clades of Anathallis species; the first is coded clade Anathallis and the second clade has been coded Lankesteriana.

Clade Lankesteriana (P.P. $=0.98$ ) includes the accessions of the species Anathallis barbulata, A. cuspidata, A. duplooyi and A. fractiflexa. A clade including Trichosalpinx berlineri and $T$. dependens (Trichosalpinx II) is highly supported (P.P. $=1$ ) as sister to the Lankesteriana clade. Sister to both is a clade including species of Zootrophion with high support (P.P. $=0.94)$.

Clade Anathallis is highly supported (P.P. $=1$ ) and includes all accessions of genus Anathallis with the exception of those found in clade Lankesteriana. Clade Anathallis includes A. obovata, type species of the genus, and $A$. sertularioides, type species of genus Panmorphia. A clade including Trichosalpinx blaisdellii and T. orbicularis (Trichosalpinx I) is found with low support (P.P. $=0.35$ ) sister to the Anathallis. Altogether they are sister, with medium support (P.P. $=0.66$ ), to a highly supported (P.P. = 1) clade which includes the accessions of Frondaria Luer, Lepanthes Sw. and Lepanthopsis (Cogn.) Ames.

Both mentioned clades are sister to each other, and in turn to an accession of Trichosalpinx arbuscula (Trichosalpinx III), with low support (P.P. = 0.44). High support (P.P. $=1)$ is found for a clade which includes all the accessions of Anathallis, Frondaria, Lepanthes, Lepanthopsis, Trichosalpinx and Zootrophion Luer.

Branch length varies greatly within the whole group. The length of accessions of clade Lankesteriana double or triple those of Anathallis, the latter having accumulated many more nucleotide changes.
Discussion . The DNA based evidence obtained here supports the results of Chiron et al. (2012), showing that Anathallis is non-monophyletic. The addition of other accessions of the variable $A$. barbulata, and of its close relatives A. duplooyi, A. cuspidata and A. fractiflexa confirms that this species group as a whole should be excluded from Anathallis. The two highly supported clades of Anathallis are not sister to each other. Most of these species had already been segregated from Anathallis into Panmorphia by Luer, together with several others. However, Panmorphia is not monophyletic. The type species of Panmorphia is a member if Anathallis s.s., necessitating a novel generic concept for the remaining species of the former Panmorphia. When describing Panmorphia, Luer (2006) suggested that he could find a "continuum of variations among them", however, he did mention that "several affinities among the species can be recognized". One of those affinities was likely this little group. In fact, this species group can also be easily distinguished from other species of the genus on morphological grounds, and they are therefore recognized as a segregate genus here forth.

\section{Lankesteriana Karremans, Gen. Nov.}

TYPE: Pleurothallis barbulata Lindl. Folia Orch. Pleurothallis 40. 1859. Replaced name for Pleurothallis barbata H.Focke, Bot. Zeitung (Berlin) 11(13): 227. 1853 (non Pleurothallis barbata Westc., Phytologist 1: 54. 1841).

Species of Lankesteriana are somewhat similar to Anathallis but can be distinguished by the tri-alate ovary (vs. cylindrical), the bilabiate flowers with lateral sepals convergent and usually fused to above the middle (vs. sepals free and spreading), the deeply depressed midline of the lip (vs. not or superficially depressed), the bilobed, helmet-shaped rostellum (vs. ligulate, not bilobed). Additionally, none of the known species of Lankesteriana have: 1) a habit that exceeds $3 \mathrm{~cm}$ tall (excluding the inflorescence), 2) ramicauls longer than the leaf, 3) multiple flowers open simultaneously on an inflorescence; 4) whitish to greenish flowers; all of which are commonly found in Anathallis.

Description: Plants very small, $0.5-3 \mathrm{~cm}$ tall (excluding the inflorescence), epiphytic, caespitose. 


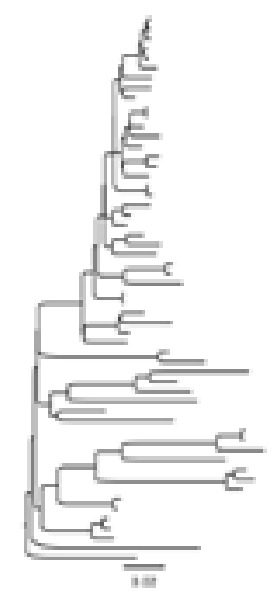

5 Arathalin nodcefi: - Anachalls piratinimgara

Lif Anathallis pubipetela F Avatalis cunobrampersis Anathalls depaperata Arathalls Inearisolla - Mnathallis cortecla Twe Arethalls kabtsing 14 Mrathalle propervaso

- Arablalls microgomme

I Arachalis nectaribra

- Anathalla belabbeded

- Anachallis mishidab

Arethalls molked

- Arethalls petropolitura

af Arathalls adenckhla (1) Arathalls abenochla (2)

T Arathallis pabnti

1 Araballs anguntiabia

- Arathallis cbovela (D)

B

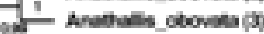

- Mrathallis cbovsa (1)

Aruthalls cieing

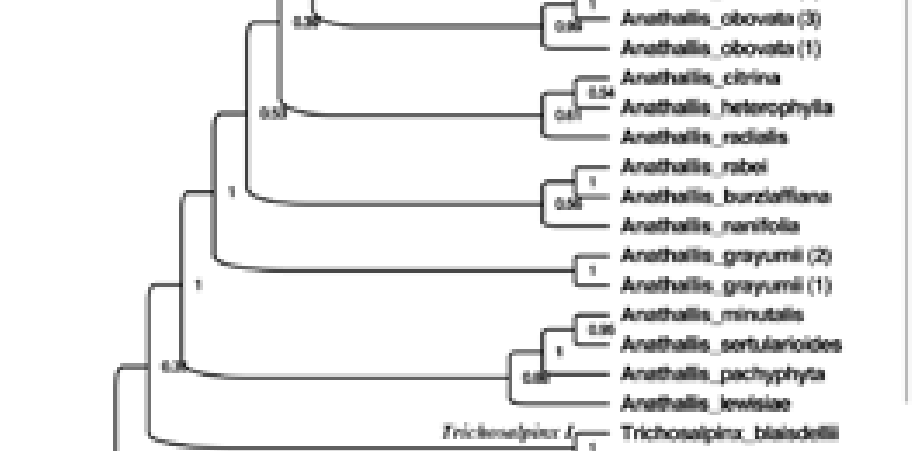

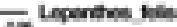

it Lepartwe noctouryane Lepaneses steyomaka Frondata cablescers

- Leperdhogeis forlyecton

I Lepentwogeis antrophora

I Anachalls fractiseas (C)

- Andhallis fractisena (1)

- Aratralls cueppida

- Anathalles duplooy

Anathalis batulats (3)

- Anachallis bartaluta (1)

Anahalis batuluta (2)

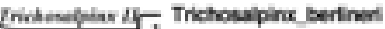

Irichosilpirs deperdens

FIgure 1. Consensus tree from a BEAST analysis of a matrix of 56 ITS sequences. The analysis ran for 20,000,000 generations. A - Branch length transformed to be equal for each species. Values on the nodes are Posterior Probabilities. Species names for each terminal is included. B - Relative branch lengths maintained, showing amount of evolutionary changes. Scale equals a $2 \%$ change. Posterior probability values and species names are excluded, but are equal to those of A. Trees edited by A.P. Karremans using FigTree. 
TABLE 1. List of vouchers and GenBank number used in the phylogenetic analyses. Scientific names mostly follow Pridgeon 2005.

\begin{tabular}{|c|c|c|c|}
\hline Taxon & $\begin{array}{l}\text { Voucher collector and } \\
\text { number }\end{array}$ & $\begin{array}{l}\text { GenBank } \\
\text { number }\end{array}$ & Source \\
\hline Anathallis adenochila (Loefgr.) F.Barros (1) & van den Berg 2148 (HUEFS) & JQ306490 & Chiron et al. 2012 \\
\hline Anathallis adenochila (Loefgr.) F.Barros (2) & Karremans 4871 (L) & KC425725 & This study \\
\hline Anathallis angustilabia (Schltr.) Pridgeon \& M.W.Chase & Manning $890604(\mathrm{~K})$ & AF262868 & Pridgeon et al. 2001 \\
\hline Anathallis aristulata (Lindl.) Luer & van den Berg 2042 (HUEFS) & JQ306338 & Chiron et al. 2012 \\
\hline Anathallis barbulata (Lindl.) Pridgeon \& M.W. Chase (1) & Chiron 11071 (HUEFS) & JQ306457 & Chiron et al. 2012 \\
\hline Anathallis barbulata (Lindl.) Pridgeon \& M.W. Chase (2) & Bogarín 8606 (JBL) & KC425726 & This study \\
\hline Anathallis barbulata (Lindl.) Pridgeon \& M.W. Chase (3) & Karremans $5750(\mathrm{~L})$ & KF747834 & This study \\
\hline Anathallis bolsanelloi Chiron \& V.P.Castro & van den Berg 2000 (HUEFS) & JQ306342 & Chiron et al. 2012 \\
\hline Anathallis burzlaffiana (Luer \& Sijm) Luer & Karremans 4857 (L) & KC425727 & This study \\
\hline Anathallis citrina (Schltr.) Pridgeon \& M.W.Chase & van den Berg 2086 (HUEFS) & JQ306498 & Chiron et al. 2012 \\
\hline $\begin{array}{l}\text { Anathallis corticicola (Schltr. ex Hoehne) Pridgeon \& } \\
\text { M.W.Chase }\end{array}$ & Hermans $3685(\mathrm{~K})$ & AF262870 & Pridgeon et al. 2001 \\
\hline Anathallis cuspidata (Luer) Pridgeon \& M.W. Chase & Bogarín 9619 (JBL) & KF747835 & This study \\
\hline Anathallis depauperata (Cogn.) & Karremans $4808(\mathrm{~L})$ & KC425735 & This study \\
\hline Anathallis duplooyi (Luer \& Sayers) Luer & Karremnas 4888 (JBL) & KF747836 & This study \\
\hline Anathallis fractiflexa (Ames \& C. Schweinf.) Luer (1) & Bogarín 8988 (JBL) & KC425728 & This study \\
\hline Anathallis fractiflexa (Ames \& C. Schweinf.) Luer (2) & Bogarín 8988 (JBL) & KC425729 & This study \\
\hline Anathallis grayumii (Luer) Luer (1) & Karremans 2747 (JBL) & KC425730 & This study \\
\hline Anathallis grayumii (Luer) Luer (2) & Pupulin 3794 (JBL) & KC425731 & This study \\
\hline Anathallis heterophylla Barb.Rodr. & van den Berg 2031 (HUEFS) & JQ306339 & Chiron et al. 2012 \\
\hline Anathallis kautskyi (Pabst) Pridgeon \& M.W.Chase & van den Berg 2051 (HUEFS) & JQ306340 & Chiron et al. 2012 \\
\hline Anathallis lewisiae (Ames) Solano \& Soto Arenas & Bogarín 1056 (JBL) & KC425733 & This study \\
\hline Anathallis linearifolia (Cogn.) Pridgeon \& M.W.Chase & Hrmans $2336(\mathrm{~K})$ & AF262869 & Pridgeon et al. 2001 \\
\hline $\begin{array}{l}\text { Anathallis microgemma (Schltr. ex Hoehne) Pridgeon \& } \\
\text { M.W.Chase }\end{array}$ & Manning $940319(\mathrm{~K})$ & AF262894 & Pridgeon et al. 2001 \\
\hline Anathallis minutalis (Lindl.) Pridgeon \& M.W.Chase & Jimenez-M. 1044 (UNAM) & AF262922 & Pridgeon et al. 2001 \\
\hline Anathallis nanifolia (Foldats) Luer & Karremans $4793(\mathrm{~L})$ & KC425736 & This study \\
\hline Anathallis nectarifera Barb.Rodr. & van den Berg 2078 (HUEFS) & JQ306458 & Chiron et al. 2012 \\
\hline Anathallis obovata (Lindl.) Pridgeon \& M.W.Chase (1) & Kollmann 6092 (MBML) & JQ306497 & Chiron et al. 2012 \\
\hline Anathallis obovata (Lindl.) Pridgeon \& M.W.Chase (2) & Stenzel $840(\mathrm{CU})$ & JF934822 & Stenzel 2004 \\
\hline Anathallis obovata (Lindl.) Pridgeon \& M.W.Chase (3) & Karremans $4796(\mathrm{~L})$ & KF747797 & This study \\
\hline Anathallis ourobranquensis Campacci \& Menini & Chiron 11220 (HUEFS) & JQ306459 & Chiron et al. 2012 \\
\hline Anathallis pabstii (Garay) Pridgeon \& M.W.Chase & Karremans 4821 (L) & KC425737 & This study \\
\hline Anathallis pachyphyta (Luer) Pridgeon \& M.W.Chase & Karremans $4795(\mathrm{~L})$ & KC425734 & This study \\
\hline Anathallis peroupavae (Hoehne \& Brade) F. Barros & Karremans 5759 (L) & KF747837 & This study \\
\hline Anathallis petropolitana (Hoehne) Luer \& Toscano & van den Berg 2089 (HUEFS) & JQ306491 & Chiron et al. 2012 \\
\hline Anathallis piratiningana (Hoehne) F.Barros & van den Berg 2066 (HUEFS) & JQ306344 & Chiron et al. 2012 \\
\hline Anathallis pubipetala (Hoehne) Pridgeon \& M.W.Chase & van den Berg 2106 (HUEFS) & JQ306460 & Chiron et al. 2012 \\
\hline Anathallis rabei (Foldats) Luer & Karremans 4794 (L) & KC425738 & This study \\
\hline Anathallis radialis (Porto \& Brade) Pridgeon \& M.W.Chase & Chiron 10144 (HUEFS) & JQ306345 & Chiron et al. 2012 \\
\hline Anathallis rudolfii (Pabst) Pridgeon \& M.W.Chase & van den Berg 2127 (HUEFS) & JQ306461 & Chiron et al. 2012 \\
\hline Anathallis sertularioides (Sw.) Pridgeon \& M.W.Chase & Solano 807 (UNAM) & AF262871 & Pridgeon et al. 2001 \\
\hline
\end{tabular}


TABLE 1. Continues.

\begin{tabular}{|c|c|c|c|}
\hline Taxon & $\begin{array}{l}\text { Voucher collector and } \\
\text { number }\end{array}$ & $\begin{array}{l}\text { GenBank } \\
\text { number }\end{array}$ & Source \\
\hline Anathallis welteri (Pabst) F.Barros & van den Berg 2009 (HUEFS) & JQ306341 & Chiron et al. 2012 \\
\hline $\begin{array}{l}\text { Echinosepala aspasicensis (Rchb. f.) Pridgeon \& M.W. } \\
\text { Chase }\end{array}$ & Hermans $2160(\mathrm{~K})$ & AF262905 & Pridgeon et al. 2001 \\
\hline Frondaria caulescens (Lindl.) Luer & Luer $18778(\mathrm{~K})$ & AF262914 & Pridgeon et al. 2001 \\
\hline Lepanthes felis Luer \& R. Escobar & Hermans $2899(\mathrm{~K})$ & AF262891 & Pridgeon et al. 2001 \\
\hline Lepanthes steyermarkii Foldats & Hermans $2682(\mathrm{~K})$ & AF262889 & Pridgeon et al. 2001 \\
\hline Lepanthes woodburyana Stimson & Hermans $2931(\mathrm{~K})$ & AF262890 & Pridgeon et al. 2001 \\
\hline Lepanthopsis astrophora Garay & Manning $941040(\mathrm{~K})$ & AF262893 & Pridgeon et al. 2001 \\
\hline Lepanthopsis floripecten (Rchb. f.) Ames & van den Berg 2063 (HUEFS) & JQ306336 & Chiron et al. 2012 \\
\hline Trichosalpinx arbuscula (Lindl.) Luer & Hermans $1266(\mathrm{~K})$ & AF262888 & Pridgeon et al. 2001 \\
\hline Trichosalpinx berlineri (Luer) Luer & Hermans $1605(\mathrm{~K})$ & AF262900 & Pridgeon et al. 2001 \\
\hline Trichosalpinx blaisdellii (S.Watson) Luer & Kew 1997-7412 (K) & AF262887 & Pridgeon et al. 2001 \\
\hline Trichosalpinx dependens (Luer) Luer & van den Berg 2011 (HUEFS) & JQ306456 & Chiron et al. 2012 \\
\hline Trichosalpinx orbicularis (Lindl.) Luer & Hermans $1349(\mathrm{~K})$ & AF262886 & Pridgeon et al. 2001 \\
\hline Zootrophion atropurpureum (Lindl.) Luer (1) & Kew 1997-7414 (K) & AF262898 & Pridgeon et al. 2001 \\
\hline Zootrophion atropurpureum (Lindl.) Luer (2) & van den Berg 2056 (HUEFS) & JQ306415 & Chiron et al. 2012 \\
\hline Zootrophion serpentinum Luer & Manning $921030(\mathrm{~K})$ & AF262899 & Pridgeon et al. 2001 \\
\hline
\end{tabular}

Ramicauls ascending, shorter than the leaf, never proliferating, with 1-3 imbricating, tubular, glandular to microscopically glandular sheaths. Leaf erect to prostrate. Inflorescence elongate, frequently exceeding the leaves, successive, with one flower open at a time. Flowers usually brownish-purple, sepals glabrous to ciliate. Ovary trialate. Sepals elliptic, acute, the lateral ones fused to above the middle or least convergent, forming a synsepal. Petals lanceolate to ovate-elliptic, widest near the middle, obtuse or acute, to acuminate, sometimes caudate. Lip oblong, to more or less pandurate, with a pair of basal sub-orbicular lobes, with a deep linear middle depression. Column winged, androclinium fimbriate-dentate, rostellum helmetshaped, with prominent lateral lobes. Anther helmetshaped. Pollinia in pairs, with reduced, granulose, whale-tail shaped caudicles (Fig. $2 \& 3$ ).

Etymology: The name honors both the Lankester Botanical Garden of the University of Costa Rica, which is celebrating 40 years of existence, and also the homonymous scientific journal Lankesteriana, International Journal on Orchidology.

Distribution AND ECOLOGY: Nineteen species of Lankesteriana Karremans are recognized here, however as is frequent with other tiny Pleurothallids, species of this genus tend to be overlooked in the field and lumped together into broad and variable species concepts. Species of Lankesteriana are distributed from southern Mexico, through Central America, the Andes, and all the way down to Bolivia and Brazil (Fig. 4). Costa Rica, Ecuador and Colombia contain the largest number of species, whereas Brazil, the center of diversity of sister genus Anathallis, has just a few Lankesteriana; they are notably absent from the Antilles. They occur between 280 and 2800 $\mathrm{m}$ in elevation, but most are found at mid elevations between 600 and $2000 \mathrm{~m}$.

Luer (1986) had noted that flowers of species here treated as Lankesteriana were similar to some species of Trichosalpinx subgen. Trichosalpinx (Trichosalpinx I \& II in Fig. 1). In fact, they resemble species of Trichosalpinx much more than Anathallis. Trichosalpinx was established by Luer for a group of species which shared the lepanthiform bracts of the stem and which did not fit well in either Draconanthes (Luer) Luer, Lepanthes or Lepanthopsis (Luer 1997), however that meant that they did not share a particular synapomorphy, and may not represent a natural grouping. The inclusion 


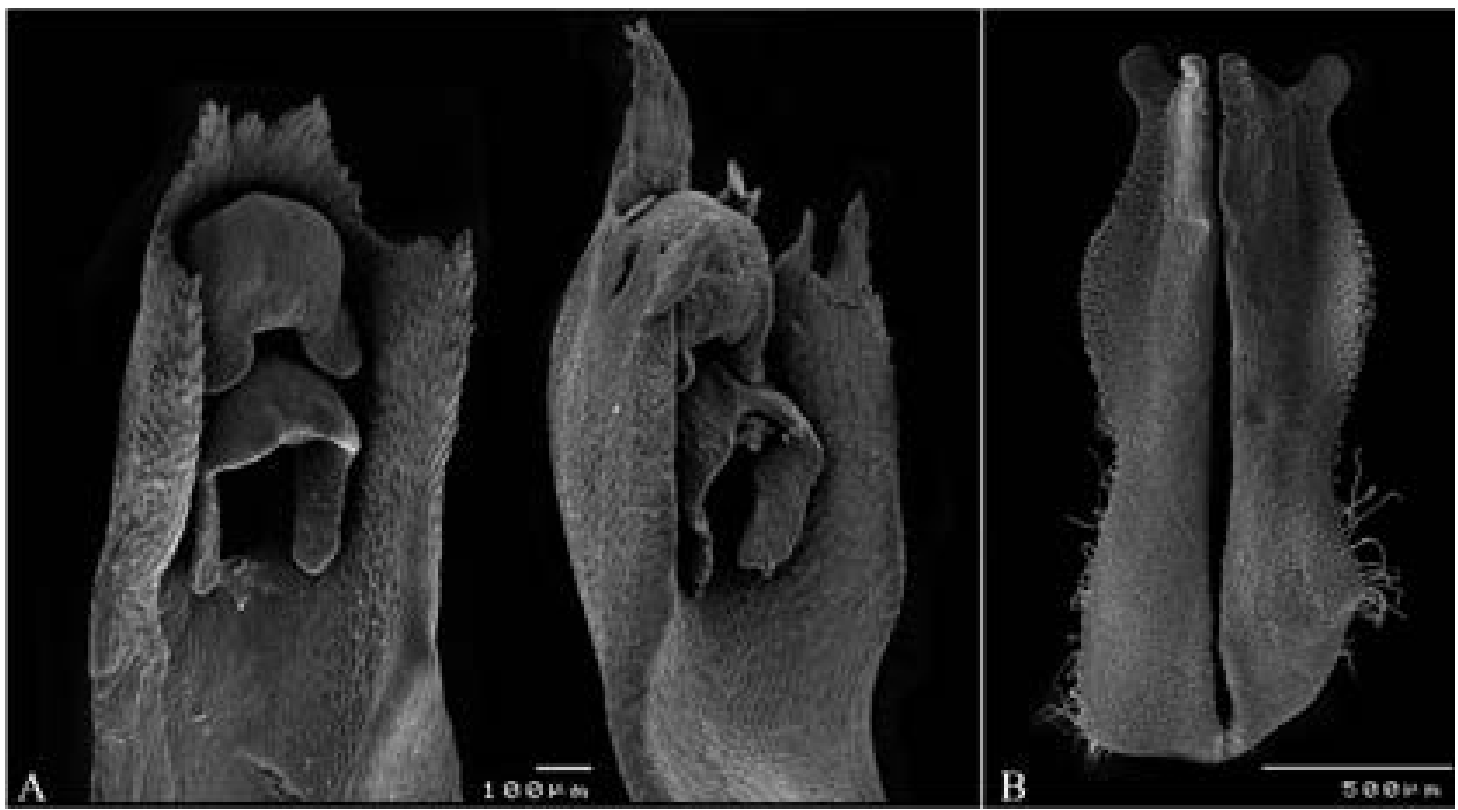

FIGURE 2. SEM images of micromorphology of Lankesteriana species. A - Column ventral view showing the androclinium, anther cap, helmet-like rostellum and stigma. B - The flattened lip, showing the midline depression, the basal sub-orbicular lobes and the glandular hairs near the apex. Specimens are Lankesteriana cuspidata (A-left \& B; Bogarin 9619; JBL-spirit) and Lankesteriana barbulata (A-right; Karremans 5444; JBL-spirit). Photographs by A.P. Karremans

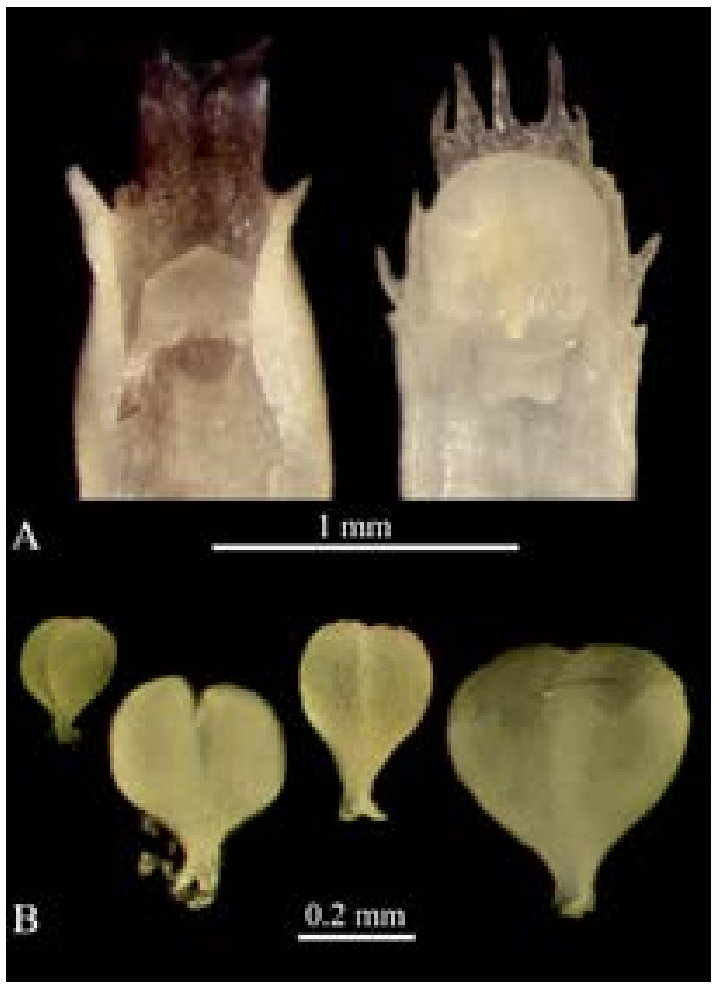

of a few species of Trichosalpinx in the DNA studies of Pridgeon et al. (2001) evidenced the polyphyly of the genus. A phylogenetic analysis of genus Trichosalpinx, including many more additional species, further evidences the need for a complete re-circumscription of this highly polyphyletic genus, which is diversely interrelated with all other genera in the clade (Fernández et al. unpublished).

Subgenus Trichosalpinx is biphyletic in the analysis presented here (Fig. 1), with a clade including the type of the genus (Trichosalpinx I), sister to Anathallis, and a second clade (Trichosalpinx II), sister to Lankesteriana. A reconsideration of Trichosalpinx will be a hazardous

Left, FIGURE 3. Micrographs taken with the Leica stereo microscope. A. Apex of the column in ventral view, from left to right, of Lankesteriana cuspidata (Fernández 695; JBL-spirit) and Anathallis polygonoides (JBL28237; JBL-spirit). B. Pollinaria, from left to right, of Lankesteriana cuspidata (Fernández 695; JBL-spirit), Anathallis polygonoides (JBL-28237; JBL-spirit), Anathallis lewisae (Bogarín 1056; JBL-spirit) and Trichosalpinx blaisdellii (Pupulin 1092; JBL-spirit). Photographs by A.P. Karremans. 


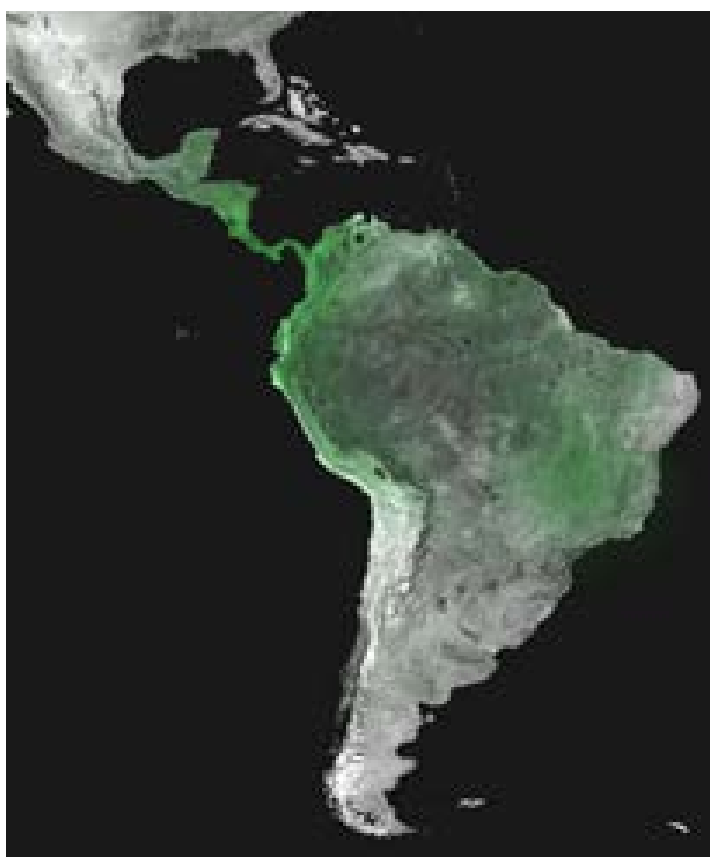

Figure 4. Distribution map (in green) of the 19 known species of Lankesteriana Karremans. The highest diversity of the genus in found from Costa Rica to Colombia and Ecuador.

task that falls outside of the scope of this study. It suffices to say that we consider sister genera Anathallis and Trichosalpinx (Trichosalpinx I) distinct enough to keep them as separate genera and that the clade which includes Lankesteriana and Trichosalpinx II was until now unnamed. When revising Trichosalpinx in the future it can be re-considered if it is advantageous to include the few species belonging to Trichosalpinx II in a broadened Lankesteriana, however, based on morphology and genetic distance, such a move is in our view unfavorable.

With species of subgen. Trichosalpinx they share the fused sepals (with a few exceptions), the usually purplish-brown flowers, the extremely sensitive linear lip, with a pair of rounded lobes at the base, and a midline depression and the helmet-shaped rostellum. These traits suggest that both groups share a similar pollinator group. Species of subgen. Trichosalpinx however can be easily distinguished from those of Lankesteriana by the much larger plants, with long ramicauls covered with lepanthiform bracts and the simultaneously multi-flowered inflorescences.
Key to the GENERA WITH SPECKLINIA-LIKE HABIT

1. Inflorescence frequently lax-flexuous, sepals usually caudate, petals fimbriate, acute to caudate, column inornate to narrowly winged

Muscarella (Specklinia)

1. Inflorescence mostly congested-straight, sepals usually not caudate, petals entire to minutely denticulate, infrequently caudate, column ornate ......... 2

2. Petals linear to lanceolate, acute to acuminate, column wings quadrate to triangular, androclinium conspicuously fimbriate 3

3. Inflorescence single or simultaneously multiflowered. Flowers star-shapped, lateral sepals free, flowers mostly white, green or yellow, lip lacking a deep mid-line depression, rostellum ligulate Anathallis

3. Inflorescence successively single flowered. Flowers bilabiate, lateral sepals fused, flowers brownish-purple, lip with deep a midline depression, rostellum helmet-like bilobate .....

Lankesteriana

2. Petals elliptic to spathulate, obtuse, column wings rounded, androclinium erose or inornate ......... 4

4. Lip mostly linear-ligulate, column wings prominent, pollinia without caudicles ............. Specklinia

4. Lip trilobed, with a pair of suborbicular lobes close to the middle, columninconspicuously ornate or inornate, pollinia with caudicles .....

Pabstiella

Lankesteriana abbreviata (Schltr.) Karremans, comb. nov.

Bas. Pleurothallis abbreviata Schltr., Repert. Spec. Nov. Regni Veg. 10: 352. 1912.

Lankesteriana barbulata (Lind1.) Karremans, comb. nov.

Bas. Pleurothallis barbulata Lindl. Folia Orch. Pleurothallis 40. 1859. Replacement name for $P$. barbata H.Focke, 1853.

Note: Specklinia pereziana Kolan. published in 2011 from Colombia, is virtually indistinguishable from Lankesteriana barbulata, a common, widely distributed, variable species with several heterotypic synonyms. As L. barbulata was not even mentioned by the author there is no evidence to separate the two. 
Lankesteriana casualis (Ames) Karremans, comb. nov.

Bas. Pleurothallis casualis Ames, Sched. Orch. 9: 30, 1925.

Lankesteriana caudatipetala (C.Schweinf.) Karremans, comb. nov.

Bas. Pleurothallis caudatipetala C.Schweinf. Bot. Mus. Leafl. 10: 175. 1942.

Lankesteriana comayaguensis (Ames) Karremans, comb. nov.

Bas. Pleurothallis comayaguensis Ames, Bot. Mus. Leafl. 4: 31, 1936.

Lankesteriana cuspidata (Luer) Karremans, comb. nov.

Bas. Pleurothallis cuspidata Luer, Selbyana 3: 282, 1977.

Lankesteriana duplooyi (Luer \& Sayers) Karremans, comb. nov.

Bas. Pleurothallis duplooyi Luer \& Sayers. Rev. Soc. Bol. Bot. 3: 48, 2001.

Lankesteriana edmeiae (F.J. de Jesus, Xim. Bols. \& Chiron) Karremans, comb. nov.

Bas. Anathallis edmeiae F.J. de Jesus, Xim. Bols. \& Chiron, Richardiana 13: 296. 2013.

Lankesteriana escalarensis (Carnevali \& Luer) Karremans, comb. nov.

Bas. Pleurothallis escalarensis Carnevali \& Luer, Novon 13: 414. 2003.

Lankesteriana fractiflexa (Ames \& C.Schweinf.) Karremans, comb. nov.

Bas. Pleurothallis fractiflexa Ames \& C.Schweinf., Sched. Orch. 10: 26, 1930.

Lankesteriana haberi (Luer) Karremans, comb. nov.

Bas. Pleurothallis haberi Luer, Selbyana 23:36. 2002.

Lankesteriana imberbis (Luer \& Hirtz) Karremans, comb. nov.

Bas. Pleurothallis imberbis Luer \& Hirtz, Lindleyana 11: 163, 1996.

Lankesteriana inversa (Luer \& R.Vásquez) Karremans, comb. nov.

Bas. Pleurothallis inversa Luer \& R.Vásquez, Rev. Soc. Bol. Bot. 3: 50. 2001.
Lankesteriana involuta (L.O.Williams) Karremans, comb. nov.

Bas. Pleurothallis involuta L.O.Williams, Bot. Mus. Leafl. 12: 239. 1946.

Lankesteriana millipeda (Luer) Karremans, comb. nov.

Bas. Pleurothallis millipeda Luer, Orquideología 20: 216.1996

Lankesteriana minima (C.Schweinf.) Karremans, comb. nov.

Bas. Pleurothallis minima C.Schweinf., Bot. Mus. Leafl. 3: 82. 1935.

Lankesteriana muricaudata (Luer) Karremans, comb. nov.

Bas. Pleurothallis muricaudata Luer, Selbyana 7: 119. 1982.

Lankesteriana rubidantha (Chiron \& Xim.Bols.) Karremans, comb. nov.

Bas. Specklinia rubidantha Chiron \& Xim.Bols., Richardiana 9: 125. 2009.

Lankesteriana steinbuchiae (Carnevali \& G.A.Romero) Karremans, comb. nov.

Bas. Pleurothallis steinbuchiae Carnevali \& G.A.Romero, Novon 4: 90. 1994.

Anathallis Barb.Rodr., Gen. Sp. Orch. Nov. 1: 23. 1877

TYPE: Anathallis fasciculata Barb.Rodr., Gen. Sp. Orch. Nov. 1: 23. 1877.

This relatively old genus remained mostly unused until it was re-established by Pridgeon and Chase (2001), and re-defined by Pridgeon (2005). It was not clear how many and which species actually belonged to the concept, but initially about 90 species were transferred. About 90 more names were added by other authors since then (mostly transfers from other genera, but also new species). If we exclude the species that belong to Lankesteriana and Stelis, we end up just shy of 140 species, a number which seems reasonable.

Species of Anathallis are distributed from southern Mexico through Central America, the Antilles and all South America down to Argentina. They are most diverse in Brazil at low to mid elevations. They are easily recognized by the more or less star-shaped flower, with linear to lanceolate, acute to acuminate petals 
that are similar to the sepals. The lip is horizontally placed and very sensitive, its general shape is linearligulate but frequently it has small lobes at the base and/or middle. The column is sharply winged and prominently fimbriate. The pollinaria come in pairs and have reduced whale-tail shaped caudicles.

One species before treated as Specklinia is transferred here to Anathallis based on those morphological features.

\section{Anathallis napintzae (Luer \& Hirtz) Karremans, comb. nov.}

Bas. Pleurothallis napintzae Luer \& Hirtz, Lindleyana 11: 173. 1996.

Stelis Sw., J. Bot. (Schrader) 2: 239. 1799.

LeCTOYPE: Epidendrum ophioglossoides Jacq., Enum. Pl. Carib., 29. 1760.

Although this genus has been traditionally accepted (Karremans et al. 2013), it was greatly modified by Pridgeon and Chase (2001) and Pridgeon et al. (2005). As such the genus was broadened from its classic definition (Luer 2009) to include several species groups before placed in Pleurothallis. Stelis in its broad sense was phylogenetically analyzed and extensively discussed by Karremans (2010) and Karremans et al. (2013), and was proven largely monophyletic if the species of Pleurothallis subgen. Acuminatia sect. Acuminatae were transferred to it. That species group was found to be closely related to the species of Stelis in a strict sense (Luer 2009). It will suffice to say here that although smaller, better defined and informative generic concepts are preferred by the author, these species are transferred to a broad sense of Stelis where they are more accurately placed than previously.

In any other scenario this species group would require generic recognition, however, several other genera would have to be recognized and/or recircumscribed as well. This might be possible at a later stage when the species belonging to each of those other groupings are well understood. The species transferred here were in any case already proven nonmonophyletic as a group by Karremans et al. (2013), however, all still within the broad concept of Stelis.

Stelis ariasii (Luer \& Hirtz) Karremans, comb. nov.
Bas. Pleurothallis ariasii Luer \& Hirtz, Lindleyana 12: 42.1997.

Stelis asperilinguis (Rchb.f. \& Warsz.) Karremans, comb. nov.

Bas. Pleurothallis asperilinguis Rchb.f. \& Warsz., Bonplandia (Hannover) 2: 114. 1854.

Stelis aurea (Lindl.) Karremans, comb. nov.

Bas. Pleurothallis aurea Lindl., Ann. Mag. Nat. Hist. 12: 397. 1843.

Replaced synonym: Dendrobium acuminatum Kunth in F.W.H.von Humboldt, A.J.A.Bonpland \& C.S.Kunth, Nov. Gen. Sp. 1: 357. $1816=$ Anathallis acuminata (Kunth) Pridgeon \& M.W. Chase.

Note: The name Dendrobium acuminatum has priority over P. aurea, however Stelis acuminata Luer \& Hirtz occupies the combination in Stelis. The heterotypic synonyms of this species, if not proven distinct and if not occupied in genus Stelis, have priority in the necessity of a new name. Therefore Stelis aurea is proposed for this species.

Stelis candida (Luer \& Hirtz) Karremans, comb. nov.

Bas. Pleurothallis candida Luer \& Hirtz, Monogr. Syst. Bot. Missouri Bot. Gard. 76: 107. 1999.

\section{Stelis catenata Karremans, nom. nov.}

Replaced synonym: Pleurothallis ramulosa Lindl., Fol. Orchid. 9: 33. 1859.

Etymology: From the Latin catenatus referring to the chains of ramicauls formed.

Note: The name Stelis ramulosa Luer \& Dalström (2004) occupies the combination in Stelis required for Pleurothallis ramulosa $[=$ Anathallis ramulosa (Lindl.) Pridgeon \& M.W. Chase]. Its heterotypic synonym Pleurothallis superposita Schltr. (1916) can't be combined in Stelis either as Stelis superposita Schltr. (1915) is also occupied. A new name for the species is therefore proposed.

Stelis coripatae (Luer \& R.Vásquez) Karremans, comb. nov.

Bas. Pleurothallis coripatae Luer \& R.Vásquez, Phytologia 46: 362. 1980.

Stelis dimidia (Luer) Karremans, comb. nov.

Bas. Pleurothallis dimidia Luer, Monogr. Syst. Bot. Missouri Bot. Gard. 76: 109. 1999. 
Stelis jesupiorum (Luer \& Hirtz) Karremans, comb. nov.

Bas. Pleurothallis jesupiorum Luer \& Hirtz, Lindleyana 11: 164. 1996.

Stelis lagarophyta (Luer) Karremans, comb. nov.

Bas. Pleurothallis lagarophyta Luer, Monogr. Syst. Bot. Missouri Bot. Gard. 76: 112. 1999.

Stelis lamprophylla (Schltr.) Karremans, comb. nov.

Bas. Pleurothallis lamprophylla Schltr., Repert. Spec. Nov. Regni Veg. 15: 205. 1918.

Replaced synonym: Pleurothallis dolichopus Schltr., Repert. Spec. Nov. Regni Veg. 10: 394. $1912=$ Anathallis dolichopus (Schltr.) Pridgeon \& M.W. Chase.

Note: The name Pleurothallis dolichopus has priority over P. lamprophylla, however Stelis dolichopus Schltr. occupies the combination in Stelis. The heterotypic synonyms of this species, if not proven distinct and if not occupied in genus Stelis, have priority in the necessity of a new name. Therefore Stelis lamprophylla is proposed for this species.

\section{Stelis lauta Karremans, nom. nov.}

Replaced Synonym: Pleurothallis concinna Luer \& R.Vásquez, Revista Soc. Boliv. Bot. 2: 133. 1999.

EтумоLоgy: From the Latin lautus, elegant, fine, as a replacement for the also Latin adjective concinnatus used in the original description of this species.

Note: The name Stelis concinna Lindl. (1834) occupies the combination in Stelis required for Pleurothallis concinna $[=$ Anathallis concinna (Leur \& R.Vásquez) Pridgeon \& M.W. Chase]. A new name for the species is proposed.

\section{Stelis lennartii Karremans, nom. nov.}

Replaced Synonym: Pleurothallis anderssonii Luer, Lindleyana 11: 145. 1996.

EтyмоLogy: The name honors Lennart Andersson, to whom the species was originally dedicated.

Note: The name Stelis anderssonii Luer \& Endara occupies the combination in Stelis required for Pleurothallis anderssonii [=Anathallis anderssonii (Luer) Pridgeon \& M.W. Chase]. A new name for the species is proposed.

Stelis maguirei (Luer) Karremans, comb. nov.

Bas. Pleurothallis maguirei Luer, Monogr. Syst. Bot. Missouri Bot. Gard. 76: 113. 1999.
Stelis mediocarinata (C.Schweinf.) Karremans, comb. nov.

Bas. Pleurothallis mediocarinata C.Schweinf., Fieldiana, Bot. 33: 26. 1970.

Stelis melanopus (F.Lehm. \& Kraenzl.) Karremans, comb. nov.

Bas. Pleurothallis melanopus F.Lehm. \& Kraenzl., Bot. Jahrb. Syst. 26: 443. 1899.

Replaced synonym: Pleurothallis stenophylla Lehm. \& Kraenzl., Bot. Jahrb. Syst. 26: $442.1899=$ Anathallis stenophylla (Lehm. \& Kraenzl.) Pridgeon \& M.W. Chase.

Note: The name Pleurothallis stenophylla has priority over P. melanopus, however Stelis stenophylla Rchb.f. occupies the combination in Stelis. The heterotypic synonyms of this species, if not proven distinct and if not occupied in genus Stelis, have priority in the necessity of a new name. Therefore Stelis melanopus is proposed for this species.

Stelis meridana (Rchb.f.) Karremans, comb. nov.

Bas. Pleurothallis meridana Rchb.f., Linnaea 22: 826. 1850.

Stelis montserratii (Porsch) Karremans, comb. nov.

Bas. Pleurothallis montserratii Porsch, Oesterr. Bot. Zeitsch. 158. 1905.

Replaced synonym: Pleurothallis rubens Lindl., Edwards's Bot. Reg. 21: t. 1797. 1835.

Note: The name Pleurothallis rubens has priority over P. montserratii, however as Stelis rubens Schltr. (1910) occupies the combination in Stelis, a new name has to be proposed in that genus. Chiron et al. (2012) proposed Stelis neorubens Chiron, however the heterotypic synonyms of this species, if not proven distinct and if not occupied in genus Stelis, have priority in the necessity of a new name. Therefore Stelis montserratii is proposed for this species and has priority over $S$. neorubens, unless it is proven a distinct species.

Stelis papuligera (Schltr.) Karremans, comb. nov.

Bas. Pleurothallis papuligera Schltr., Repert. Spec. Nov. Regni Veg. 10: 453. 1912.

Stelis regalis (Luer) Karremans, comb. nov.

Bas. Pleurothallis regalis Luer, Selbyana 5: 178. 1979 . 
Stelis scariosa (Lex.) Karremans, comb. nov.

Bas. Dendrobium scariosum Lex. in P.de La Llave \& J.M.de Lexarza, Nov. Veg. Descr. 2(Orchid. Opusc.): 39. 1825.

Stelis schlimii (Luer) Karremans, comb. nov.

Bas. Pleurothallis schlimii Luer, Monogr. Syst. Bot. Missouri Bot. Gard. 76: 120. 1999.

Stelis sclerophylla (Lindl.) Karremans, comb. nov.

Bas. Pleurothallis sclerophylla Lindl., Edwards's Bot. Reg. 21: t. 1797. 1835.

Stelis soratana (Rchb.f.) Karremans, comb. nov.

Bas. Pleurothallis soratana Rchb.f., Xenia Orchid. 3: 25.1881 .

Stelis spathilabia (Schltr.) Karremans, comb. nov.

Bas. Pleurothallis spathilabia Schltr., Repert. Spec. Nov. Regni Veg. Beih. 27: 56. 1924.

Stelis spathuliformis (Luer \& R.Vásquez) Karremans, comb. nov.

Bas. Pleurothallis spathuliformis Luer \& R.Vásquez, Revista Soc. Boliv. Bot. 2: 137. 1999.

Stelis unduavica (Luer \& R.Vásquez) Karremans, comb. nov.

Bas. Pleurothallis unduavica Luer \& R.Vásquez, Phytologia 46: 372. 1980.

Stelis vasquezii (Luer) Karremans, comb. nov.

Bas. Pleurothallis vasquezii Luer, Phytologia 49: 220. 1981.

Conclusions. High species diversity and the many cases of convergence and parallelism make the systematics of the Pleurothallidinae quite hazardous. Morphological features are often congruent with phylogenetic hypotheses based on DNA data, but homoplasy can occur in morphological traits; similar morphological features may not always reflect a similar evolutionary history. Molecular data provide an independent data set that can be used to evaluate morphological homoplasy. Several modifications to the genera Anathallis, Specklinia and Stelis have been proposed here in an effort to circumscribe genera that are both monophyletic and diagnosable using morphological characters. With the exclusion of the species belonging to Lankesteriana and Stelis, the recircumscribed Anathallis is monophyletic based on all available data.

It must be stressed that the present work does not intend to be a molecularly based phylogenetic study of Anathallis and Lankesteriana. Instead, a systematic re-circumscription of those genera is proposed using an all evidence approach in which clear morphological patterns are correlated with available DNA evidence. The analyses of additional genetic regions and of a broader species set might refine the phylogenetic relationships among these species, however, as already evidenced in several earlier studies the basic phylogenetic reconstruction produced using a representative number of nrITS sequences is mostly found unchanged (Pridgeon \& Chase 2001; Karremans 2010; Karremans et al. 2013), especially when the found clades have been thoroughly characterized morphologically (Luer 2002; Karremans 2010).

Lankesteriana (Fig. 5) is a well supported and defined genus of some 19 species. They are widely distributed in the Neotropics with the noteworthy exception of the Antilles. The genus is phylogenetically closely related to some species of Trichosalpinx and Zootrophion, however, the tiny habit with an extremely reduced ramicaul with adpressed inconspicuous bracts, and the relatively long successively single flowered inflorescences resemble species of Anathallis and Specklinia much more closely. On the other hand, the frequently purplish flowers with usually fused lateral sepals and an extremely sensitive lip are once again reminiscent of some species of Trichosalpinx subgen. Trichosalpinx.

ACKNOWLEDGMENTS. I am thankful to the Costa Rican Ministry of Environment and Energy (MINAE) and its National System of Conservation Areas (SINAC) for issuing the Scientific Passports under which wild species treated in this study were collected. My colleagues Franco, Diego and Melania at Lankester Botanical Garden have been most insightful, and have helped with the collecting and documenting the studied material. Some of data was produced as part of the research projects under supervision of Barbara Gravendeel in diverse

Right, FIGURE 5. Representative species of genus Lankesteriana. A — Lankesteriana barbulata (Karremans 5187; JBLspirit). B - Lankesteriana barbulata (Karremans 5447; JBL-spirit) C — Lankesteriana cuspidata (Bogarín 9619; JBL-spirit). D — Lankesteriana duplooyi (Karremans 4888; JBL-spirit). E — Lankesteriana fractiflexa (Bogarín 8988; JBL-spirit). F — Lankesteriana sp.nov. (Karremans 4900; JBL-spirit). Photographs by A.P. Karremans. 


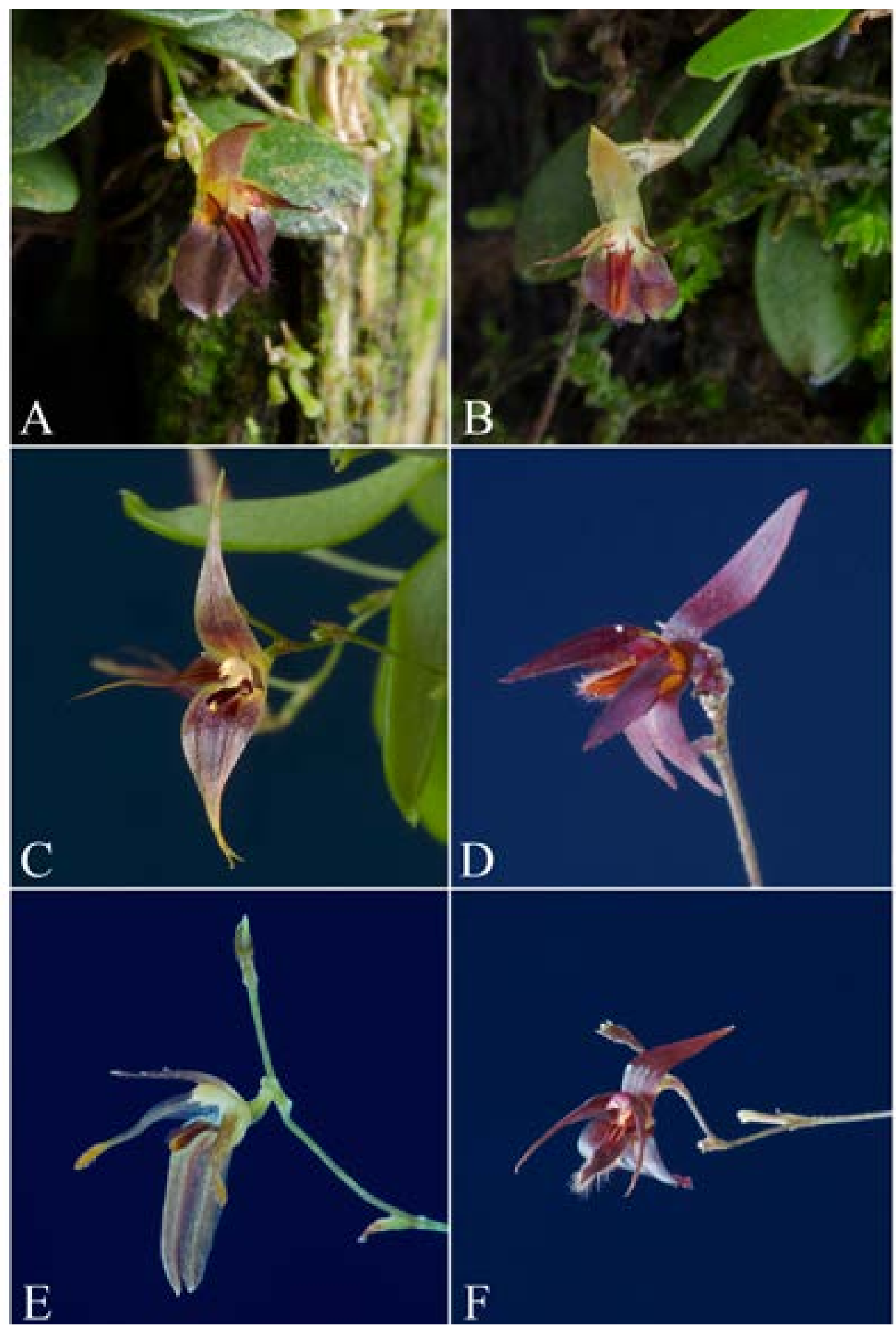


labs at Leiden University and the Naturalis Biodiversity Center. In general I wish to thank all the staff of JBL and L for the unrestricted access and help. I am most thankful to Lio and Ibra for the delight they have been during this period. Lisa Thoerle and two other anonymous reviewers made a series of improvements to the manuscript, and I am very thankful to them. I am also in debt to the Vice-Presidency of Research of the University of Costa Rica for providing support through the projects "Inventario y taxonomía de la flora epífita de la región Mesoamericana" (814-A7-015), "Flora Costaricensis: Taxonomía y Filogenia de la subtribu Pleurothallidinae (Orchidaceae) en Costa Rica" (814-BO-052), "Filogenia molecular de las especies de Orchidaceae endémicas de Costa Rica" (814-B1-239) and "Taxonomía, filogenia molecular, aislamiento reproductivo y diferenciación de nichos de Specklinia endotrachys" (814-B3-075).

\section{LiterATURE CITED}

Bogarín, D., A.P. Karremans, R. Rincón \& B. Gravendeel. 2013. A new Specklinia (Orchidaceae: Pleurothallidinae) from Costa Rica and Panama. Phytotaxa 115(2): 31-41.

Chiron, G.R., J. Guiard \& C. van den Berg. 2012. Phylogenetic relationships in Brazilian Pleurothallis sensu lato (Pleurothallidinae, Orchidaceae): evidence from nuclear ITS rDNA sequences. Phytotaxa 46: 34-58.

Drummond, A.J. \& A. Rambaut. 2007. BEAST: Bayesian evolutionary analysis by sampling trees. BMC Evol. Biol. 7: 214.

Heneghan C, M. Thompson, M. Billingsley \& D. Cohen. 2011. Data from: Medical-device recalls in the UK and the device-regulation process: retrospective review of safety notices and alerts. Dryad Digital Repository. http:// dx.doi.org/10.5061/dryad.585t4.

Karremans, A.P. 2010. Phylogenetics of Stelis (Orchidaceae: Pleurothallidinae) and closely related genera, based on molecular data, morphological characteristics and geographical distribution in the Central American and Andean Cordilleras. MSc Thesis, Plant Sciences Group and Biosystematics Group, Wageningen University.

Karremans, A.P., F.T. Bakker, F. Pupulin, R. Solano-Gomez \& M.J.M. Smulders. 2013a. Phylogenetics of Stelis and closely related genera (Orchidaceae: Pleurothallidinae). Plant Syst. Evol. 29(1): 69-86.

Karremans, A.P., F. Pupulin \& B. Gravendeel. 2013 b. Taxonomy, molecular phylogenetics, reproductive isolation, and niche differentiation of the Specklinia endotrachys species complex (Orchidaceae: Pleurothallidinae). Lankesteriana 13(1-2): 132-133.

Luer, C.A. 1986. Systematics of the genus Pleurothallis (Orchidaceae). Mongr. Syst. Bot. Missouri Bot. Gard. 20. Luer, C.A. 1997. Systematics of Trichosalpinx. Monogr. Syst. Bot. Missouri Bot. Gard. 64.
Luer, C.A. 1999. lcones Pleurothallidinarum XVIII. Systematics of Pleurothallis Subgen. Pleurothallis Sect. Pleurothallis Subsect. Antenniferae, Subsect. Longiracemosae, Subsect. Macrophyllae-Racemosae, Subsect. Perplexae, Subgen. Pseudostelis, Subgen. Acuminatia. Mongr. Syst. Bot. Missouri Bot. Gard. 76.

Luer, C.A. 2002. A systematic method of classification of the Pleurothallidinae versus a strictly phylogenetic method. Selbyana 23(1): 57-110.

Luer, C.A. 2006. Icones Pleurothallidinarum XXVIII. Reconsideration of Masdevallia, and the Systematics of Specklinia and vegetatively similar genera (Orchidaceae). Mongr. Syst. Bot. Missouri Bot. Gard. 105.

Luer, C.A. 2009. Icones Pleurothallidinarum XXX. Lepanthes of Jamaica and Systematics of Stelis, Stelis of Ecuador, part four and addenda: systematic of Masdevallia, new species of Lepanthes from Ecuador, and miscellaneous new combinations. Mongr. Syst. Bot. Missouri Bot. Gard. 115.

Maddison, W.P. \& D.R. Maddison. 2007. Mesquite: a modular system for evolutionary analysis. Mesquite v. 2.72. Available at http://mesquiteproject.org

Pridgeon, A.M. \& M.W. Chase. 2001. A phylogenetic reclassification of Pleurothallidinae (Orchidaceae). Lindleyana 16(4): 235-271.

Pridgeon, A.M., R. Solano, M.W. Chase. 2001. Phylogenetic relationships in Pleurothallidinae (Orchidaceae): combined evidence from nuclear and plastid DNA sequences. Am. J. Bot. 88(12): 2286-2308.

Pridgeon, A.M. 2005. Subtribe Pleurothallidinae. In: A.M. Prigeon, P.J. Cribb, M.W. Chase \& F.N. Rasmussen (Eds.), Genera Orchidacearum. Volume 4 Epidendroideae (Part One). Pp. 319-422.

Pupulin, F., A.P. Karremans \& B. Gravendeel. A reconsideration of the empusellous species of Specklinia (Orchidaceae: Pleurothallidinae) in Costa Rica. Phytotaxa 63: 1-20.

Rambaut, A. 2009. FigTree v1.3.1. Available at http://tree. bio.ed.ac.uk/software/

Staden, R., D.P. Judge \& J.K. Bonfield. 2003. Analysing Sequences Using the Staden Package and EMBOSS. In: S. A. Krawetz and D. D. Womble (Eds.), Introduction to Bioinformatics. A Theoretical and Practical Approach. Human Press Inc., Totawa, NJ 07512.

Stenzel, H. 2004. Systematics and evolution of the genus Pleurothallis R. Br. (Orchidaceae) in the Greater Antilles. Dissertation Thesis. MathematischNaturwissenschaftlichen Fakultät I der HumboldtUniversität zu Berlin.

Sun, Y., D.Z. Skinner, G.H. Liang \& H. Hulbert. 1994. Phylogenetic analysis of Sorghum and related taxa using internal transcribed spacers of nuclear ribosomal DNA. Theor. Appl. Genet. 89: 26-32. 